Arq. Bras. Med. Vet. Zootec., v.68, n.1, p.66-72, 2016

\title{
Diagnostic value of computed tomography, radiography and ultrasonography in metacarpophalangeal joint disorders in horses
}

\author{
[Importância diagnóstica da tomografia computadorizada, radiografia e ultrassonografia \\ nas afeç̧ões da articulação metacarpofalangeana em equinos] \\ V.M.V. Machado ${ }^{1}$, A.C.S. Aguiar $^{2}$, G.F. Viana ${ }^{2}$, N.O. Crosignani ${ }^{2}$, J.N.P. Puoli Filho ${ }^{1}$ \\ ${ }^{1}$ Faculdade de Medicina Veterinária e Zootecnia - UNESP - Botucatu - SP \\ ${ }^{2}$ Alunos de pós-graduação -Faculdade de Medicina Veterinária e Zootecnia - UNESP - Botucatu, SP
}

\begin{abstract}
In modern society the work and athletic performance of horses has led to a very important animal production sector in which Brazil possesses the third largest horse stock. Among all equine lesions described, metacarpophalangeal (fetlock) joint lesions are considered one of the main causes of lameness. Consequently, there is a need to improve the understanding and diagnosis of these injuries. The most efficient imaging diagnostic methods for the fetlock region are computed tomography, radiography and ultrasound. Imaging studies of the anatomical structures involving this joint are extremely important to obtain a more precise diagnose. The present study was performed in order to evaluate the capacity of different imaging diagnostic modalities to detect a variety of lesions in different fetlock structures. Twenty horses (Equus caballus) used for horsemanship activities were referred to the Department of Animal Reproduction and Veterinary Radiology of São Paulo State University, Botucatu campus, with clinical signs of metacarpophalangeal joint injuries. Horses were submitted to radiographic and ultrasonographic exam and computed tomography scan. Image analysis revealed a significant capacity of these methods to characterize lesions in this region. However, computed tomography provided broader and better evaluation of lesions in bones and adjacent structures, because it allows the analysis to be performed on three-dimensional projections, with attenuation coefficients (window selections) and tissue density measurement through Hounsfield Units (HU).
\end{abstract}

Keywords: computed tomography, radiography, ultrasonography, metacarpophalangeal joint, horses

\section{RESUMO}

As atividades desempenhadas pelo cavalo na sociedade contemporânea são diversas, e o Brasil é portador do terceiro maior plantel mundial de equinos. Entre as várias afecções descritas em cavalos atletas, as lesões na articulação metacarpofalangeana (boleto) são consideradas as principais causas de claudicação. Por isso, continuamente se aprofunda o conhecimento no diagnóstico das enfermidades que acometem essa região. Dentre as modalidades de diagnóstico por imagem, os exames de tomografia computadorizada, radiografia e ultrassonografia constituem os mais eficazes para avaliação da região do boleto. Com o presente trabalho, teve-se como objetivo avaliar o desempenho da tomografia computadorizada, da radiografia e da ultrassonografia nas mais variadas injúrias das estruturas da articulação metacarpofalangeana. Vinte cavalos (Equus caballus), destinados às atividades de horsemanship, foram encaminhados ao Departamento de Reprodução Animal e Radiologia Veterinária da Universidade Estadual Paulista, campus de Botucatu, com sinais clínicos de afecções na articulação metacarpofalangeana. Os animais foram submetidos aos exames de radiografia, ultrassonografia e tomografia computadorizada. As imagens revelaram grande capacidade dos métodos em caracterizar lesões nessa articulação. Entretanto, a tomografia computadorizada possibilitou avaliar de modo mais amplo e aprimorado as lesões em estruturas ósseas e adjacentes dessa articulação, pois permite a análise das imagens por meio de projeções tridimensionais, a seleção de coeficiente de atenuação $e$ a mensuração da densidade dos tecidos em unidade Hounsfield (HU).

Palavras-chave: tomografia computadorizada, radiografia, ultrassonografia, articulação metacarpofalangeana, equinos

Recebido em 9 de agosto de 2014

Aceito em 16 de setembro de 2015

E-mail: vaniamvm@fmvz.unesp.br 


\section{INTRODUCTION}

The metacarpophalangeal joint, also known as fetlock, presents a ginglymus aspect and consists of the distal extremity of the third metacarpal bone (IIIMC), first phalanx (P1), proximal sesamoid bones (PSB) and the intersesamoidean ligament, which secures the PSB along their axial aspect (Riegel and Hakolla, 2001; Ross and Dyson, 2003). Among all lesion sites, the fetlock is considered one of the main causes of lameness in athlete horses (Uelstchi et al., 1996; Vanderperren and Saunders, 2009).

According to Santchi (2008), fetlock lesions are classified into soft or bone tissue, and overload, acute, traumatic or developmental orthopedic disease (Ross and Dyson, 2003). The most commonly reported pathologic conditions are sesamoiditis and fractures, which represent a significant drop in the performance of affected animals (Dyson, 2007).

Imaging diagnosis is extremely important to identify lameness causes, location, lesion severity and extension. Due to its growth in recent years, the necessity to elucidate the different techniques and their applicability in cases of lameness has resulted in improvement. Some imaging techniques include radiographs, ultrasound and computed tomography (CT), the latter of which allows a more detailed and precise diagnosis (Park et al., 2006). Gaschen and Burba (2012) describe that an association of multiple imaging modalities is indicated to obtain a precise evaluation of musculoskeletal lesion in horses.

Therefore, the present study aimed to evaluate the performance of computed tomography (CT), radiographs and ultrasound (US) in detecting different lesions in fetlock structures, and to suggest the most appropriate imaging modality for this region.

\section{MATERIAL AND METHODS}

Twenty horses (Equus caballus) used for horsemanship activities with clinical signs of fetlock injuries were referred to the Department of Animal Reproduction and Veterinary Radiology of São Paulo State University, campus at Botucatu. Animals undertook radiographic exam, followed by ultrasonographic and CT scans. Only one limb per animal was used for this study.
Radiographs were taken by an Eco Ray® portable X-ray machine, model Orange $1060 \mathrm{HF}$ with $100 \mathrm{Kvp}$ of power and a 37 x $28.5 \mathrm{~cm}$ detector. Fetlock radiographic projections performed were lateromedial, dorsopalmar dorsolateral-palmaromedial oblique $45^{\circ}$, dorsomedial-lateropalmar oblique $45^{\circ}$. Trabecular bone, signs of osteocondritis, subchondral sclerosis or lysis, cortical and subcontral bone lesions and joint space, among other possible changes, were evaluated in all images.

After the radiographic exam an ultrasound was performed using scanning equipment from Esaote ${ }^{\circledR}$, Model MyLab 70 and $10 \mathrm{MHz}$ linear transducer. Images were obtained in transversal and longitudinal sections and recorded for later evaluation. All exams were performed with the animal standing and without any need for sedation. Parameters evaluated were: thickness, echogenicity and margin integrity of the following structures: medial and lateral collateral sesamoidean ligaments, suspensory ligaments, flexor and extensor tendons, intersesamoidean and distal sesamoidean ligament, synovial lining, joint space and bone cortical margin.

The CT exam was performed using a CT helicoidal scanner Shimadzu, model SCT7800TC. Contiguous slices of $1 \mathrm{~mm}$ thickness transverse images of bilateral metacarpophalangeal joints were acquired using $120 \mathrm{kVp}$ and $200 \mathrm{mAs}$. Images were then reconstructed on sagittal and coronal planes and in 3D using Voxar 3D version 6.3. In order to position the horses' limbs, an equine CT table for large animals, model SOLVING SAPT 1C-MR MAX Load $1000 \mathrm{~kg} /$ Pressure 3 bar was used. Trabecular bone, signs of osteochondritis, subchondral sclerosis or lysis, cortical and subcontral bone lesions were evaluated.

Animals were anesthetized according to the Veterinary Hospital protocol. For pre-anesthetic medication xylazine $(0.5 \mathrm{mg} / \mathrm{kg})$ was injected intravenously (IV) and diazepam $(0.1 \mathrm{mg} / \mathrm{kg})$ and ketamine $(2.2 \mathrm{mg} / \mathrm{kg})$ IV were applied for induction. General anesthesia was maintained with isoflurane vaporized in pure oxygen.

This study was approved by Sao Paulo State University Ethics Committee (232/2011 CEUA). 


\section{RESULTS}

Radiographic images allowed the identification of osteochondritis, subchondral bone sclerosis, irregular periosteal reaction, osteophytes, enthesophytes and joint space reduction. Out of the 20 total limbs radiographed, 6 (30\%) presented signs of sesamoiditis. Radiographs of ostechondritis were identified as sagittal ridge changes (chronic proliferative synovitis) of the third metacharpal bone (IIIMC) in 1 limb (5\%). Joint space reduction and subchondral sclerosis was present in 2 limbs $(10 \%)$ and osteophytes also in 2 limbs $(10 \%)$. Enthesopathy was observed in dorsolateral-palmaro-medial $45^{\circ}$ oblique projection in 3 limbs $(15 \%)$. These projections evidenced bone margin irregularities in lateral and medial distal epicondylar fossa of IIIMC in the enthesis topography of collateral fetlock ligaments (Figure 1).
CT scans provided information on joint borders, periarticular surface and subchondral bone (Figure 2).

It was also possible to evaluate bone margins in joint capsule and ligament incision topography. Furthermore, the tissue attenuation coefficient, given in Hounsfield units (HU), allowed the identification of changes such as sclerosis and other soft tissue changes in density. Sagittal, dorsal and tridimensional (3D) reconstructions provided detailed information regarding the fetlock (Figure 3).

The most evident of the tomographic findings were bilateral subchondral sclerosis and irregular periosteal reaction in medial and lateral proximal phalanx margin, characterizing fetlock collateral ligament enthesopathy in 5 limbs $(25 \%)$ and desmopathy in 3 limbs (15\%) (Figures 4 and 5).

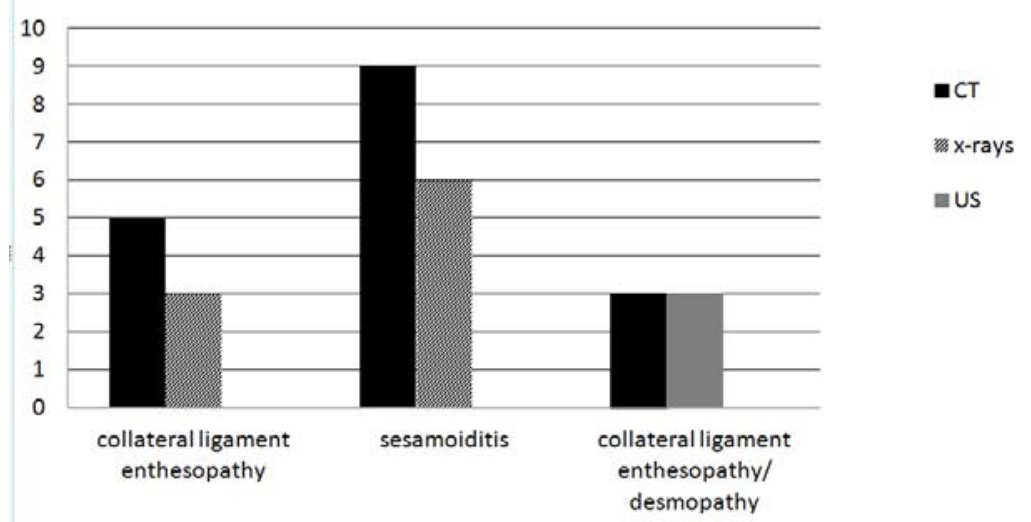

Figure 1. Horse. Graphic representation of animals presenting signs of sesamoiditis, collateral ligament enthesopathy/desmopathy on radiographic (x-rays), ultrasonographic (US) and computed tomography (TC) evaluations.

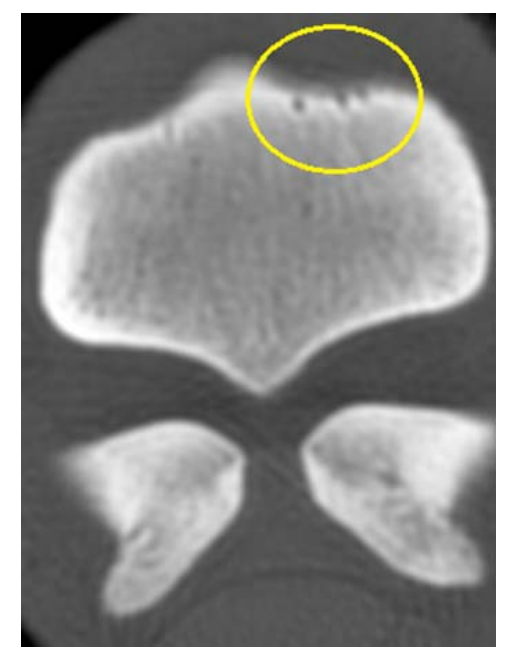

Figure 2. Horse. Amplified transverse plane from tomographic image presenting discrete subchondral bone irregularity on dorsal margin of the third metacarpal bone (yellow ellipse). 

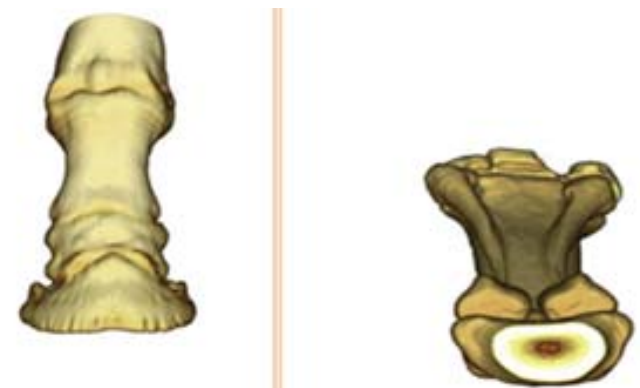

Figure 3. Horse. 3D reconstruction showing metacarpophalangeal joint in dorsal and axial views.

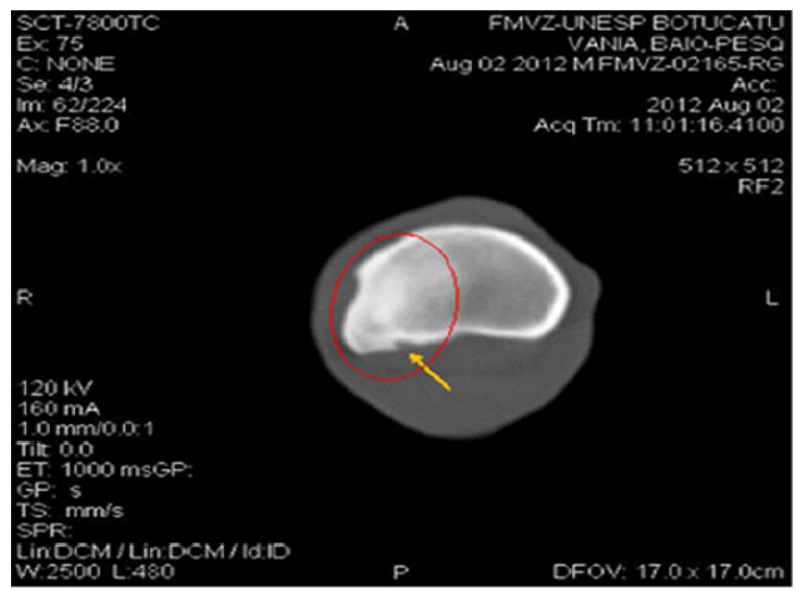

Figure 4. Horse. Transverse plane computed tomographic image presenting attenuation coefficient in the selected bone tissue. Bone margin irregularity, highlighted by the yellow arrow, is characteristic of P1 enthesophyte. Subchondral sclerosis is indicated by the red ellipse [HU: 1532 (HU reference: 521)].

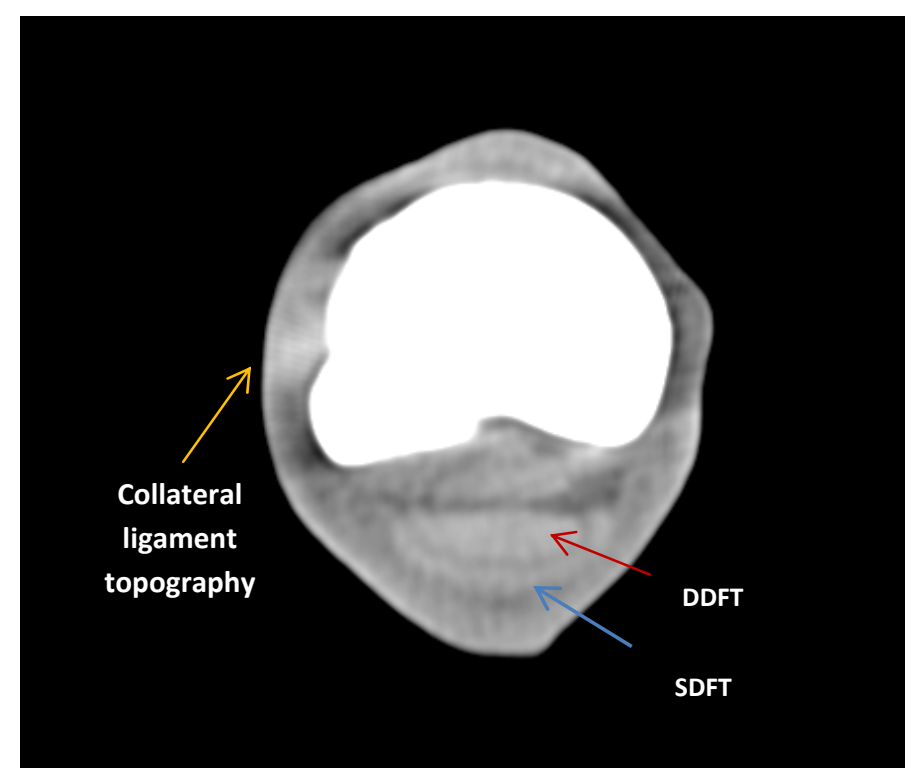

Figure 5. Horse. Axial plane computed tomographic image indicating attenuation coefficient in the selected area. Image shows hyperdense area in proximal lateral border of proximal phalanx, in lateral collateral ligament topography (yellow arrow) [HU: 166 (HU reference: 33)]. Deep Digital Flexor Tendon (DDFT) and Superficial Digital Flexor Tendon (SDFT) are indicated by the blue and red arrow, respectively. 
In 9 limbs $(45 \%)$ the proximal sesamoid bone presented a heterogeneous attenuation coefficient and irregular border (Figure 1). Osteoarthritis and subchondral sclerosis affected 2 limbs $(10 \%)$, whereas synovitis and capsulitis were present in 1 limb (5\%).

\section{DISCUSSION}

Matacarpophalangeal join radiographs were performed in four standard projections: lateromedial, dorsopalmar, dorsolateralpalmaromedial oblique $45^{\circ}$, dorsomediallateropalmar oblique $45^{\circ}$ as mentioned by Butler et al. (1993), and Vanderperren and Saunders (2009). In this study, sesamoiditis and enteshopathys were observed in dorsolateralpalmaromedial oblique $45^{\circ}$ and dorsomediallateropalmar oblique $45^{\circ}$ views. Radiographs also allowed the identification of ostrochondrosis signs in the sagittal ridge, even though complementary radiographs were not taken for further investigation. The lateromedial view with flexed fetlock provided better images of the sagittal ridge, while the lateromedial view with the limb suspended and extended is indicated for visualization of erosive bone and cartilage lesions in the palmar aspect of IIIMC (Butler et al., 1993; Vanderperren and Saunders, 2009). Furthermore, due to chronic lesions it was possible to identify radiograph images consistent with proliferative synovitis and osteoarthritis in all views. As mentioned by Park (2006), radiographic exam is sensitive to identify proximal sesamoid bone changes. Thus, sesamoiditis presented a higher incidence of diagnosis than other changes. However, CT was more sensitive to proximal sesamoids evaluation than radiographs (Figure 1). This sensitivity is believed to be caused by axial plane images, which allow a more precise visualization of some areas when compared to x-rays, i.e. axial margins of sesamoid bones, because they present little definition on radiographs. Furthermore, CT was more sensitive for assessing bone sclerosis and irregular abaxial surface in proximal sesamoids, results also found by Wisner et al. (1991). However, this study did not identify cavitary lesions on proximal sesamoid bones.

CT presented great sensitivity for defining subchondral bone and identify sclerosis, thus confirming the studies of Park (2006) and Puchalski (2011) that state that CT efficiency complements the information from radiographs.
Therefore, in this study, it was possible to observe subchondral bone changes such as irregularities, specifically hyperdense areas, which provide additional information and a more precise evaluation (Figure 4).

As mentioned by Puchalski (2011), transverse plane images obtained from direct scan can provide reconstructions in different planes and give tridimensional information; therefore, this study considered that 3D images were very precise regarding visualization, topographic identification and lesion extension. However, the spatial resolution of images produced by CT does not surpass the high definition of contrast between the tissues, generated by magnetic resonance images for the diagnosis of degenerative musculoskeletal diseases (Olive et al., 2010).

In the region of interest (fetlock), radiography does not provide complete visualization of the extent of condylar fractures, when compared to methods that produce transversal images, such as $\mathrm{CT}$, that permit better evaluation of the palmar and plantar aspects. Nevertheless, for detecting osteochondral fragments in the dorsal region of the proximal phalanx, radiography is the most indicated diagnostic method (Morgan et al., 2006).

Prominent among the principal limitations faced when performing $\mathrm{CT}$, the need to submit the horse to an anesthetic protocol (Viana et al., 2014), which can facilitate accidents during the process of anesthetic induction and recuperation, as well as generate adverse reactions to the pharmacos employed in this procedure.

Wrigley (2006) also noticed that ultrasound presented many advantages when investigating soft tissues pertaining to the metacarpophalangeal joint and was complementary to the radiographic exam, especially in identifying desmopathy and tendinopathy because an ultrasound scan is highly sensitive for diagnosing changes in theses tissues. However, this study found that CT scans can identify bone lesions associated with soft tissue lesions, i.e., desmitis and entesopathy. CT presented a similar percentage as ultrasonography in diagnosing collateral ligament desmopathy and entesopathy even though ultrasound is the standard exam for evaluating tendons and ligaments (Figure 1). 
These results were attributed to lesion chronicity and CT technique adjustments, by selecting the attenuation coefficient in soft tissue window, which accentuated mineralization and fibrogenic changes (Figure 5). The main observation regarding CT was that it allowed a precise evaluation of enthesis and ligament density, which was also reported by Widmer et al. (2000) when they evaluated bone lesions and adjacent structures.

CT, ultrasonographic and radiographic images were complementary for the evaluation of the fetlock joint, which is in agreement with Gaschen and Burga (2012) who stress the importance of the association of different imaging methods to evaluate musculoskeletal injuries in horses. Therefore, among the modalities studied, CT presented additional information in relation to radiographs and ultrasound scans because it allows reconstructions and presents attenuation coefficient values.

\section{CONCLUSION}

The association among different imaging modalities such as CT, radiography and ultrasound is important because they complement each other's information on the metacarpophalangeal joint. CT scans allow a broader and better evaluation of bone lesions and fetlock adjacent structures because they provide tridimensional images, attenuation coefficient values through windows and tissue density in Hounsfield units (HU). Therefore, this study highlighted the importance and applicability of $\mathrm{CT}$ in joints.

\section{ACKNOWLEDGEMENTS}

Authors would like to thank FAPESP for its financial support.

\section{REFERENCES}

BUTLER J.A.; COLLES C.M.; DYSON S.J; et al. Clinical radiology of the horse. Oxford: Blackwell Scientific Publication, 1993. p.53-71.

DYSON, S.J. Diagnosis and management of common suspensory lesions in the forelimbs and hind limbs of sport horses. Clin. Tech. Equine Pract. v.6, p.179-188, 2007.
GASCHEN L.; BURGA D.J. Musculoskeletal injury in thoroughbred racehorses: correlation of findings using multiple imaging modalities. Vet. Clin. Equine, v.28, p.539-561, 2012.

MORGAN, J.W., SANTSCHI, E.M., ZEKAS L.J. et al. Comparison of radiography and computed tomography to evaluate metacarpo/metatarsophalangeal joint pathology of paired limbs of thoroughbred racehorses with severe condylar fracture. Vet. Surg., v.35, p.611617, 2006.

OLIVE, J.; D'ANJOU, M.A.; GIRARD, C.; et al. Fat-suppressed spoiled gradient-recalled imaging of equine metacarpophalangeal articular cartilage. Vet Radiol Ultrasound, v.51, p.107$115,2010$.

PARK, R.D.; WRIGLEY, R. H.; STEYN, P. F. Diagnóstico por imagem,. In: STASHAK, T.S. (Ed.). Claudicação em equinos segundo Adams. 5.ed. São Paulo: Roca, 2006. p.153.

PARK, R.D. Diagnóstico por imagem,. In: STASHAK, T.S. (Ed.). Claudicação em equinos segundo Adams. 5.ed. São Paulo: Roca, 2006. p.153-276.

PUCHALSKI, S.M. Computed tomography. In: ROSS, M.W.; DYSON, S.J. (Eds.). Diagnosis and management of lameness in the horses. 2.ed. Philadelphia: Elsevier-Saunders, 2011. p.234239.

RIEGEL, R.J.; HAKOLLA, S.E. Illustrated atlas of clinical anatomy and common disorders of the horse. Philadelphia: Elsevier-Saunders, 2011. p.126-132. Vol.1. Muscoskeletal system and lameness disorders.

ROSS, M.W.; DYSON, S.J. Diagnosis and management of lameness in the horse. Philadelphia: Elsevier-Saunders, 2003. p.368362, 1030-1031.

SANTSHI, E.M. Articular fetlock injuries in exercising horses. Vet. Clin. North Am., Equine Pract. v.24, p.117-132, 2008

UELTSCHI, G., VOSWINKEL, K., LAUK, H.D. Scintigraphical and radiological examination of fetlock-joints in clinically sound and lame horses. Pferdeheilkunde, v.12, p.25-32, 1996. 
VANDERPERREN， K.; SAUNDERS， J.H. Diagnostic imaging of the equine fetlock region using radiography. 1. Soft Tissues. Vet. J., v.181, p.111-122, 2009.

VIANA, G.F.; AGUIAR, A.C.S.; BUENO, L.M.C. et al. Tomografia computadorizada e ressonância magnética na avaliação musculoesquelética em equinos atletas: revisão de literatura. Rev. Bras. Med. Equina, v.55, p.1420, 2014.

WIDMER, W.R.; BUCKWALTER, K.A.; FESSLER, J.F, et al. Use of radiography, computed tomography and magnetic resonance imaging for evaluation of navicular syndrome in the horses. Vet. Radiol. Ultrasound. v.41, p.108116,2000 .
WISNER, E.R.; O'BRIEN T.R.; POOL R.R. et al. Osteomyelitis of the axial border of the proximal sesamoid bones in seven horses. Equine Vet. J., v.23, p.383-389, 1991.

WRIGLEY, R.H. Diagnóstico por imagem. In: STASHAK, T.S. (Ed.). Claudicação em equinos segundo Adams. 5 ed. São Paulo: Roca, 2006. p.279-309. 